\title{
Analyze the Influence of Talent Management and Knowledge Management on Employee Performance through Employee Retention as Intervening Variable at PT Bhanda Ghara Reksa Divre I Medan
}

\author{
Nidya Banuari ${ }^{1}$, Yeni Absah ${ }^{2}$, Elisabet Siahaan ${ }^{3}$ \\ ${ }^{1}$ Postgraduate Students Department of Management, Faculty of Economics and Business at University of \\ Sumatera Utara, Indonesia \\ ${ }^{2,3}$ Postgraduate Lecturer Department of Management, Faculty of Economics and Business at University of \\ Sumatera Utara, Indonesia
}

Corresponding Author: Nidya Banuari

\begin{abstract}
Employee performance is one of the most important things to achieve company goals. With employee performance, company optimization can be realized. PT Bhanda Ghara Reksa's performance in 2019 experienced a decline in revenue so that the profit target generated was not maximized. In order to improve employee performance, the company must design a strategy to retain potential employees. One of them is the application of a talent management and knowledge management. The objective of this research was to analyze the influence of talent management and knowledge management on employee performance through employee retention as intervening variable at PT Bhanda Ghara Reksa Divre I Medan. The research used descriptive quantitative approach and explanatory research method. The population in this research are permanent employees as many as 74 respondents, taken by using saturated sample with census sampling technique. The method in analyzing the data is descriptive and inferential statistical analysis with using path analysis and Sobel test to test the significance of the intervening variable. The result of the research showed that talent management had positive and significant influence on employee retention, knowledge management had positive and significant influence on employee retention, employee retention had positive and significant influence on employee performance, talent management
\end{abstract}

had positive and significant influence on employee performance, knowledge management had positive and significant influence on employee performance, talent management had positive and significant on employee performance through employee retention, and knowledge management had positive and significant on employee performance through employee retention. Knowledge management most dominantly affects employee retention and employee retention most dominantly affects employee performance.

Keywords: Talent Management, Knowledge Management, Employee Retention, Employee Performance

\section{INTRODUCTION}

The success of a company can be measured from human resources who are talented and have a lot of knowledge that companies have to manage human capital. According to Adiba (2018), it is important to balance the needs of employees and the ability of the company comes from the management of human resources. According to Qustolani (2017), the employee is the main wheels of a company achieve its goals. According to the Harmen (2018), one of the few things important to achieve the goal of the company is employee performance. With the performance of the employees of the 
optimum of the company can be realized. Every company requires the employee's performance to the maximum that will give an impact on the achievement of targets and goals of the company.

PT Bhanda Ghara Reksa or better known as BGR Logistics is the State-Owned Enterprises engaged in warehousing services, management of indoor and delivery of the goods. Network BGR Logistics consists of 9 branches and 14 subbranches that spread in all over Indonesia. The warehouse belongs BGR Logistics for rent as a place to store goods production to other companies.

Every year the demand for leasing warehouse continues to increase, but have not yet fully the request can be fulfilled. This is due to the availability of warehouse that is managed there are more or not comparable with the employees at BGR Logistics who served as the Head of the Warehouse which amounts to 19 (nineteen) people. Workload exceeds the capacity can result in the maximum performance of the employee.

In addition to the focus in improving the performance of employees by creating quality human resources, the company also must be able to do the draft strategy to defend the human resources potential. A lot of things that can be done by the company to obtain and retain employees in the organization, one of its forms, namely the implementation of the system management talents and knowledge management. By hiring workers potentially, the company can maximize the performance of employees to achieve the desired goal. So the retention of employees (employee retention) as a variable that mediates the relationship of management talent and knowledge management on the performance of employees.

Until the end of 2019, the number of employees BGR Logistics as much as 1.314 people who fill a variety of positions at various levels of organization that is spread all over Indonesia. Employees BGR Logistics scattered on the Division I Field a total of 74 people. This number is fewer than in 2018 as many as 99 people and 113 people in the year 2017. The following details regarding the recruitment and the level of employee turnover happens in the BGR Logistics throughout the year 2019 as follows:

Table 1: Data Employee Turnover

\begin{tabular}{|l|l|l|l|l|l|}
\hline $\mathbf{2 0 1 7}$ & $\mathbf{2 0 1 8}$ & $\mathbf{2 0 1 9}$ \\
\hline $\begin{array}{l}\text { New Employees } \\
(\%)\end{array}$ & $\begin{array}{l}\text { Employee Exit } \\
(\%)\end{array}$ & $\begin{array}{l}\text { New Employees } \\
(\%)\end{array}$ & $\begin{array}{l}\text { Employee } \\
\text { Exit }(\%)\end{array}$ & $\begin{array}{l}\text { New Employees } \\
(\%)\end{array}$ & $\begin{array}{l}\text { Employee Exit } \\
(\%)\end{array}$ \\
\hline $8(6,6)$ & $16(13,2)$ & $12(11,3)$ & $23(21,6)$ & $18(20,8)$ & $33(38,2)$ \\
\hline
\end{tabular}

Table 1 show that the data of recruitment and turnover rate of employees throughout the year 2019, where the number of recruitment and employee turnover managed BGR Logistics increased. If employee turnover is increased, then the retention of employees categorized as bad so give a negative impact on the performance of the employees. On the data it can be seen that the company has reduced the employee to perform the selection process of the employees who already work with do Management Development Program (MDP) that is, such as assessment, academic potential test, a test of analytical thinking as well as psychological tests to get employees more potential and meet the qualifications the company so that the number of employees who get out more because there can be expected position and chose to resign from the company. Employees who choose to come out due to the company not be able to retain the employee so that the employee submitted to a second party (Outsourcing). This is due to the lack of competence and skills of employees in the implementation of such selection. The company not only see the background and skills of prospective employees but also look at the aspects of efficiency and effectiveness of employee performance can be seen from the results of 
the workload analysis across levels of the organization.

One of the developments undertaken by the company is to implement a system of management talent. Management talent is a process to ensure the ability of the company fills the position of the key future leaders of the company (company future leader) and the position of the supporting competence the core of the company, Pella \& Afifah (2011). Data management talents on BGR Logistics obtained from the results of interviews with Department Business Support stating that so far BGR Logistics has conducted training which will create skills and skills to cultivate the talents of employees. For a new employee trainingtraining and development will be monitored in doing the work. After passing the training, the employee will be placed in a position in accordance with his expertise. Then will enter the panel of the promotion which provided the company with the terms and conditions of the company. For employees who get a promotion for his achievements during the work, passed the assessment in PPM will make the process of Management Development Program (MDP) travelled for six months in order to improve the abilities and talents of employees as of the next Company's Future Leader.

Since the adoption of management talents in 2018, of course, there are various kinds of obstacles and problems faced by BGR Logistics. One of them is that there are still many employees who do not qualify for assessment provided by the company, even more so most of the employees who work more than 5 years. In addition, the system of recruitment and selection in previous years that have not yet formal cause the company's difficulty in placing employees in accordance with their competence. BGR Logistics middle to make improvements in the aspect of Human Resources at mid-year 2019, such as by performing pembahruan job profile in collaboration with the consultant and prepare a career path as a form of program kaderasasi employees.
In addition to talent management, knowledge also plays an important role in preparing qualified human resources and competitive. Given the intense competition of today's global, the company should be able to create human resources that have a lot of knowledge to push the performance of employees to achieve company goals. By applying the knowledge management, a company can perform a variety of innovation and renewal that continues to grow.

According to the Harmen (2018) knowledge management (knowledge management) is a series of the process of creation, communicating, and applying knowledge of the company as a learning to improve the performance of employees and organization. Knowledge management is how to manage the knowledge of employees in the organization as effectively and efficiently as possible. Every company needs to realize that the knowledge of which is owned in a company should be utilized review effectively and efficiently. The company continues to perform the development of employee competencies through the implementation of various workshops to hone soft skills and hard skills. Workshop that includes a number of modules that are given to employees from various levels and departments.

Problems faced BGR Logistics that have the process of knowledge management, exchange of knowledge explicit (exchange) and tacit (meeting), but not used to manage respondensi and knowledge related to the work in the field of logistics. There are still many employees who are not able to recognize and understand it better, because it does not have the sensitivity and awareness of the impact for the company. A lack of knowledge both tacit and explicit about the work of the employees one of which resulted in a lot of error (human error) so as to make the quality of work of employees decreased. The quality of work of employees can be seen from the knowledge 
they have, this is because knowledge is a thing that continues to experience growth.

Researchers are interested to do research on the management talents and knowledge management. Because at the end of this topic such as this become a primary issue in the problems of Human Resources Management. The day the increasing number of human resources. However, whether all the quality of human resources? Of course not. Just some of the human resources who have the ability and meet the requirement of the company. Required competent human resources in a company to be able to create progress, but in reality the number of workers tools is very limited. Of course, the company will be racing and competing to get competent employees.

In line with research conducted by Katili, et.al (2015), Ogbeta (2015), Mahlala (2018) stated that the management of taenta positive and significant effect on employee performance. Khanal (2017), Garcia \& Coltre (2017) stated that knowledge management has significant effect on employee performance. The results of these studies supported by Rahmawati (2019), which examines the influence of talent management programmes on employee performance through employee retention, Harmen (2018) stated that the management of talent and knowledge management has a significant influence on employee performance.

\section{LITERATURE REVIEW Management Talent}

The management of talent is as organizational procedures related to analyze, identify, selection, training, development, motivation, and maintain the performance and the highest potential of the employees to achieve the goals of the strategy (Valverdeet al., 2013).

\section{Knowledge Management}

Knowledge management is a process of helping corporate identity, select, organize, disseminate, and send important information as well as expertise included parts of memory organization that is located in a typical in organissasi in the area of structured (Turban, et al 2010).

\section{Employee Retention}

Employee Retention is defined as the ability of the company to maintain a potential employee owned company to remain loyal to the company (Ahmad, 2011).

\section{Employee Performance}

Performance is the result of work that can be accomplished by a person or group of people in an organization, in accordance with the authority and responsibility of each in order to achieve the goals of the organization concerned is legal, does not violate the law and in accordance with the norms and ethics of (Prawirosentono, 2014).

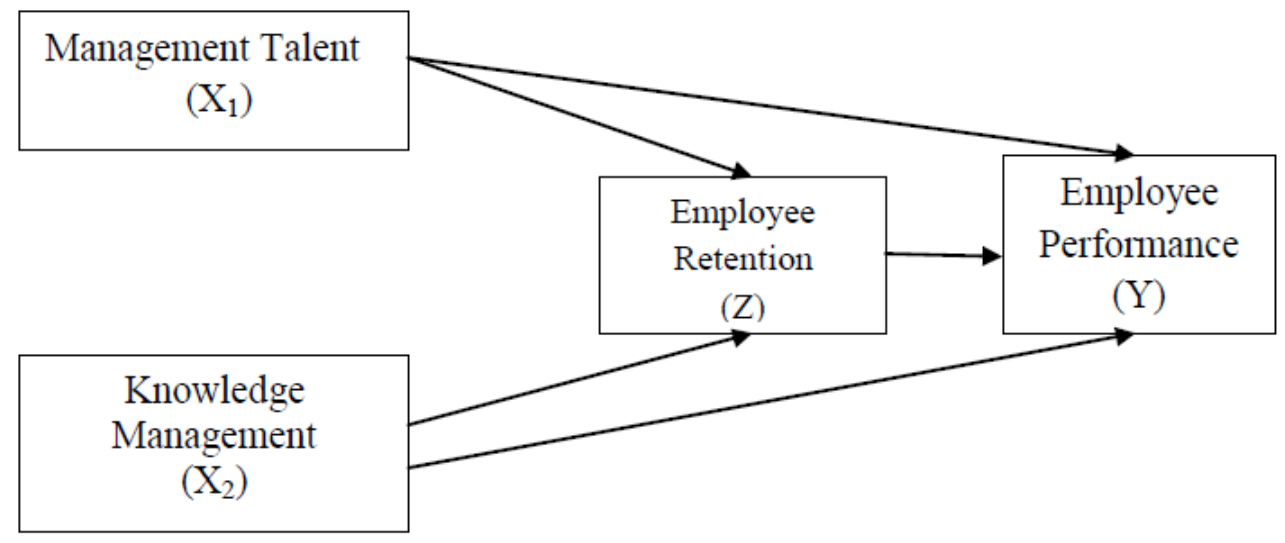

Figure 1. Conceptual Framework 


\section{Hypothesis}

Based on the background research and the relationship between variables, then the research hypothesis:

1. Management talents positive and significant effect on employee retention.

2. Knowledge management has positive and significant effect on employee retention.

3. Employee retention has positive and significant effect on employee performance.

4. Management talent has positive and significant effect on employee performance.

5. Knowledge management has positive and significant effect on employee performance.

6. Management talent has positive and significant effect on employee performance through employee retention.

7. Knowledge management has positive and significant effect on employee performance through employee retention.

\section{MATERIAL AND METHODS}

This research is a type of research that uses quantitative research that uses survey and questionnaire as a data collection tool. According to Sugiyono (2015) states regarding the quantitative method is a research method that is based on the philosophy of positivism, is used to examine the population and sample specific, using a data collection instrument of the study, quantitative data analysis/statistics with the aim to test the hypothesis set. As for the nature of this research is explanatory. According to Arikunto (2011), the nature of descriptive research explanatory research is aimed to explain the position of the variables studied and the relationship between the variables with other variables. The nature of this research is explaining phenomena that occur in the object of research about the influence of management talent and knowledge management on the performance with the retention of employees as an intervening variable at PT Bhanda Ghara Reksa Division I Field.

This study will be conducted in PT Bhanda Ghara Reksa Division I Field which is located at Jalan Titi Pahlawan Medan Marelan, Medan, Sumatera Utara. Implementation of this research was planned from July 2020 until April 2021

The population in this research is all employees in the BGR Logistics 74 people. Given the number of population is limited, then all members of the population as the sample of the study. Data collection method used in this research is interview (Interview) directly to obtain the necessary data to management and employees BGR Logistics. A list of questions (quesionare) given to employees BGR Logistics and documentation Studies, namely the collection of data through documents related to the problem under study.

The type and source of the data collected in this research is using primary Data is Data obtained directly from the list of questions (quesionare) were distributed to the respondents and the interview (the interview) to employees BGR Field and secondary Data are data that support the primary data obtained from company documents through the study of documentation, such as records or official documents of the company, the media, the company Website, the internet, journals that had to do with research, and previous research.

\section{RESULTS}

\section{Test Asusmsi Classic}

\section{Testing Assumptions The Classical Equations Structural 1}

Based on the Table 2 it can be seen that the value of the coefficient..of determination (Adjusted R Square) by 0,611 or $61,1 \%$ means the influence of management talent and management knowledge of employee retention BGR Logistics is $61.1 \%$ and the rest by $38,9 \%$ influenced by other factors not examined in the study this, it is estimated variables, 
Nidya Banuari et.al. Analyze the influence of talent management and knowledge management on employee performance through employee retention as intervening variable at PT Bhanda Ghara Reksa Divre I Medan.

Table 5: Results The t test. Equations Structural 2

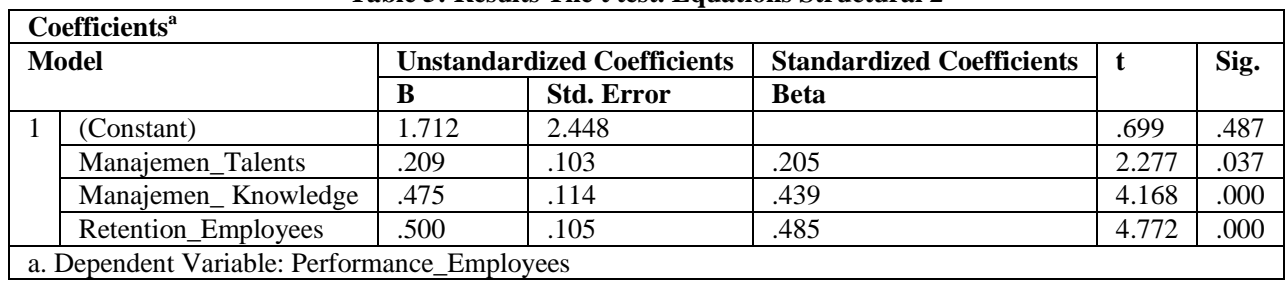

Source : Results.The study, 2021 (data processed)

Based on Table 5 looks of the value of the partial test results of the equation structural 2 be aware that variable retention of the employees earn the highest rated by 0,485 , the next variable knowledge management earned value amounted to 0.439 and variable management talents of
0,205 meaning that influence employee retention against the performance of the employees greater than the influence of management talents against the performance of the employees and influence knowledge management. on performance employees.

\begin{tabular}{|c|c|c|c|c|c|}
\hline Independent Variable & Dependent Variable & Intervening & Direct & Indirect & Total \\
\hline Manajemen Talents (X1) & \multirow[t]{2}{*}{ Retention Employees (Z) } & & 0,241 & & 0,241 \\
\hline Manajemen Knowledge (X2) & & & 0,604 & & 0,604 \\
\hline Manajemen Talents (X1) & \multirow[t]{3}{*}{ Performance Employees (Z) } & \multirow[t]{2}{*}{ Retention Employees (Z) } & 0,205 & 0,116 & 0,321 \\
\hline Manajemen Knowledge (X2) & & & 0,439 & 0,292 & 0,731 \\
\hline Retention Employees (Z) & & & 0,485 & & 0,485 \\
\hline
\end{tabular}

In Table 6 shows the influence between the variables of the study has been summarized. Influence what happens on the basis of the results of the regression between the variables of research is a direct influence between variables. Indirect effects included the presence of an intervening variable in the calculation of such influence. The result of the multiplication between the direct effect between the independent variable on the variable mediation and other intervening variable on the dependent variable are called the indirect effect.

\section{DISCUSSION}

\section{Management Talents Positive And Significant Effect On Employee Retention}

Based on the test Path Coefficient that management talents positive and significant effect on employee retention in BGR Logistics. This means that the higher management talents will also increase employee retention, on the contrary the lower the management talents then it will decrease as the retention of employees.

Management talent has a close connection with the retention of employees, companies can improve employee retention through the efforts of human resource management by applying a system of management talents high. The application of management talents can be done by the company by attracting talented employees. The process of attracting talented employees based on criteria that consider the vision and mission of the company is to perform the recruitment of talented employees and a selection of career development. Where the indicator selection career development have the highest value. This is because the company gives the employees an opportunity to be selected in following the development of the talents that his career can be increased so that the company can maintain the employee with the provisions that have been set.

So also with the process of the development of talented employees, where education and training as the indicator. This process is built on the ability of the talent of employees, the needs of the company, and the requirements of the job, as well as limit the weaknesses of employees to fill the gap which will increase the chances of 
employees in order to continue productive work. On the dimensions of the strategy of succession, the company requires the development of the staff of the company, prepare the employee to accept a job when it is needed and does not leave a chance at a job in a company. Indicators of the strategy of succession are to provide adequate support and provide real opportunities to employees to show his talent. It is intended that the preservation of the level of retention of employees in the company.

The results of the analysis of the descriptive statistics on the variables of management talent of the respondents ' answers showed that the management of the talents that are applied by BGR Logistics on average already categorized either. Good for a dimensional attract talented employees, the development of talented employees, strategy and visible succession of respondents ' answers are mostly answered agree and strongly agree. Employees who follow the process rekrumen search of talented employees, get a chance selected to participate in the development of talent, given the opportunity to participate in education and training, given adequate support, and given real opportunities can improve the retention of employees at BGR Logistics.

The results of this study are in line with previous research conducted by Phelister (2016) the research results prove that the talent management programmes have a significant influence on employee retention. The most important step of management talent is talented employees in the companies that make the company's need to retain employees in the organization. It is also supported by Ratnawati (2018) to indicate the presence of a significant impact of management talents to the retention of employees. Research conducted by the Rahmawati (2019) stated that management talents to have a positive influence and significant impact on employee retention. It is also supported by research conducted Sulistiyana (2021) which states that the management talents and significant positive effect on employee retention.

\section{Knowledge Management Has Positive And Significant Impact On Employee Retention}

Based on the test results of the Path Coefficient shows that the management of knowledge and significant positive effect on employee retention in BGR Logistics. Meaning that the higher the knowledge management will also increase employee retention, on the contrary the lower the management of knowledge then it will decrease as the retention of employees. Knowledge management is the most influential factor in the strategic future which will operate as the basis of competitive intensity for the company. Knowledge management is also closely related to the attitudes and behavior of employees on the job so that the employee can survive on the company and the views and suggestions are well received in the company.

Implementation of knowledge management can be done by finding the knowledge gained from the work experience that is owned by the employees themselves or work experience boss and get easy access to the SOP that exist in the company to obtain information. This can help the employees to develop the knowledge so that employees are able to survive in the company. The processes of making knowledge (knowledge capture) either explicit or tacit, which are within the employee, can be obtained by following the seminar/workshop for working in the company and get the facility of search of knowledge work environment that has been provided by the company.

Knowledge of the explicit or tacit can be communicated back to the process of knowledge sharing, where the indicators that a knowledge sharing culture and the availability of a group of social media. So also with the process of the application of knowledge, where by applying the knowledge can help work as well as can 
help in decision making. The process of such a good impact on the employees to be able to renew knowledge in order to compete so that the company can retain the employee.

The results of the analysis of the descriptive statistics on the variables of knowledge management regarding the respondents' answers showed that knowledge management applied by BGR Logistics on average already categorized either. Good for the dimensions of knowledge, capture knowledge, knowledge, and application of knowledge seen from the respondents ' answers are mostly answered agree and strongly agree. Through the concept of knowledge management, can help BGR Logistics to face its competitors and creates a employee-an employee who has a new innovation for the progress of the company.

The results of this study are in line with the results of the research Surbakti (2016) that proves that the knowledge management and business intilejen emphasize the empowerment of employees. Employees are empowered and have the freedom to participate in the decision in an organization. The contract of employment has a significant effect in attracting and retaining asset skilled as a key to strategic work in modern work. So the research stated that knowledge management has significant effect on employee retention. In line with the results of research conducted by Ramadhani (2020) show that knowledge management has a positive influence and significant impact on employee retention.

\section{Employee Retention Has Positive And Significant Effect On Employee Performance}

Based on the test Path Coefficient shows that the retention of employees has positive and significant effect on employee performance at BGR Logistics. This means that the higher employee retention will also increase the performance of employees, on the contrary the lower the retention of employees, it will decrease the performance of the employee. The interconnectedness of the retention of employees with employee performance is a process where employees are encouraged to remain at the company in the maximum period of time or until the completion of the target company where the employee retention has benefits for both employers and employees.

Efforts to increase the performance of employees are done by the development of a career that can affect the level of employee retention significantly. Opportunities for personal development bring up the reason why individuals take the job this time and why they last. indicators of the underlying is training employees to continue the company, development and career guidance to our employees, as well as the planning of formal career in the company. Real rewards received by employees-shaped salary, incentives and benefits. All three of these things is a reason to survive or get out of the company, but is not the only reason. Employees tend to survive if awarded competitive. Awards are competitive can be done in the form of salary and benefits are competitive, meritbased performance, the recognition of employees as well as the benefits and special bonuses.

Fundamental things that affect employee retention is the nature of the task and the job done. The design task and a good job should pay attention to the elements of responsibility and autonomy of the work, the flexibility of employment, good working conditions (factors of physical and non-physical), and the balance or the life of the employees. So also with the relationship that is owned by its employees within the company. Employee relations, including the fair treatment or not discriminatory for each employee, the support comes from the supervisor or management and employee relations with fellow colleagues. It is a supporting factor can BGR Logistics do to be able to retain its employees so that it can create good performance. 
The results of the analysis of the descriptive statistics on the variables in employee retention regarding the respondents' answers showed that the retention of employees who there are at BGR Logistics on average already categorized either. Good for the dimensions of career opportunities, award, design of tasks and jobs, as well as employee relations seen from the respondents answers are mostly answered agree and strongly agree.BGR Logistics megupayakan for retaining the employees in order not to experience a loss in the job so that the BGR Logistics need to develop the steps necessary company.

The results of this study are in line with research conducted Princess \& Arwiyah (2019) which shows that employee retention significantly positive effect on employee performance with the contribution of $92 \%$. It is also supported by Susilo (2019) the results of his research stated that there is a significant influence of employee retention and customer satisfaction on employee performance.

\section{Management Talent Has Positive And Significant Effect On Employee Performance}

Based on the test Path Coefficient shows that management talent has positive and significant effect on employee performance at BGR Logistics. This means that the higher management talents will also increase the performance of employees, on the contrary the lower the management talent it will decrease the performance of the employee. By applying management talents then the employee can improve their performance with the talents that exist in the employees. Employees can follow the process of talent management programmes as a form of career improvement will have an impact on the performance of employees to achieve a common goal among employees and the company.

This can be seen on the dimensions of the development of talented employees in the education indicators with a statement of the 3rd that I was given the opportunity to follow the education to be able to increase my potential, further indicators of training with the statement to-4 that I was given the opportunity to attend the training in accordance with the type of job where I am on the second statement has a high value, because of the development of talented employees in the statement can assist employees in improving and developing the talents so that employees are able to improve their performance.

The results of the analysis of the descriptive statistics on the variables of management talent of the respondents ' answers showed that the management of the talents that are applied by BGR Logistics on average already categorized either. Good for a dimensional attract talented employees, the development of talented employees, strategy and visible succession of respondents ' answers are mostly answered agree and strongly agree. Through management talents, BGR Logistics can manage the talents of employees based on the performance of the employees themselves.

The performance of the employee who will either create the success of a company where employees who have the potential and talent will be more easy to complete the work given company. A system of management talent in the BGR Logistics one of them is to be able to improve employee performance and also the performance of the company. Education, training, support, and opportunities is the most important thing that is given BGR Logistics to be able to improve the performance of employees through a system of management talent that is applied on the BGR Logistics.

The results of this study are in line with research conducted by Katili, et.al (2015) which revealed that the variable management talent has positive and significant effect on employee performance. This is supported by research conducted by Harmen (2018) revealed that management 
talent has positive and significant effect on employee performance.

\section{Knowledge Management Has Positive And Significant Effect On Employee Performance}

Based on the test Path Coefficient shows that the management of knowledge has positive and significant effect on employee performance at BGR Logistics. Meaning that the higher the knowledge management will also increase the performance of employees, on the contrary the lower the management of knowledge then it will decrease the performance of the employee. With knowledge management, an employee can acquire, capture, sharing, and using knowledge to enhance learning and performance in a company. Knowledge management can also give a big impact on a company inside the company there are employees who have the knowledge and develop the knowledge to be able to improve the performance of employees so that it helps the company in achieving its goals.

This can be seen in the dimensions of knowledge sharing on the indicators of a knowledge sharing culture with the statement-5 that companies foster a culture of knowledge sharing among employees, next on the indicators of the availability group social media with a statement of the 6th century, namely the company provides a group of social media as a place to exchange information at which both of these statements have a value of high, due to the sharing of knowledge on such statements can help employees to acquire the knowledge easily, so it can accelerate the completion of the work. So also with the dimensions of the application of knowledge where there are on indicators of knowledge that helps work on the statement of the 7th that is the knowledge I have accelerate the completion of my work further on indicators of knowledge to help decision-making with the statement of the 8th that is the knowledge I have can help me in making optimal decisions, where the second statement shows that with the application of knowledge by employees, it can improve the performance of employees who will be impacted is also good for the company to achieve the objectives of the company.

The results of the analysis of the descriptive statistics on the variables of knowledge management regarding the respondents answers showed that knowledge management applied by BGR Logistics on average already categorized either. A good knowledge management will affect the performance of the employees because the employees need the knowledge to carry out the direction of the task and routine as well as can make the optimal decisions to advance the company. By applying the knowledge management can help BGR Logistics in evaluating its performance, better performance of employees and the performance of the company so that in the future BGR Logistics can easily refine and develop their ability to innovate.

This research is in line with research conducted Torabi, et.al (2016) indicates the presence of a significant impact of knowledge management on employee performance. It is also supported by Saeed (2016) that the results of his research stated that there is significant influence of job satisfaction and knowledge sharing on employee performance. Research conducted Suryanti (2021) stated that knowledge management has positive and significant effect on employee performance.

\section{Management Talent Has Positive And Significant Effect On Employee Performance Through Employee Retention}

Based on the test Path Coefficient shows that the management of the talents has positive and significant effect on employee performance through employee retention, then the hypothesis 6 is accepted. The results of the research hypothesis suggest that management talent has positive and significant effect on employee performance at BGR Logistics through 
employee retention. Based on the results of the calculation of the influence directly or indirectly showed that the retention of the employees is able to provide mediation partially between the management of talent on employee performance. Influence in the form of indirect can be said as the influence of the variables of talent management programmes on employee performance through employee retention.

The influence of the mediation is partial in the variable retention of employees at BGR Logistics, where the company focuses not only in creating the human resources potential, but the company should also conduct design strategy as a form of maintaining such employee by giving the opportunity to follow the career development process on the system management talents so that employee performance can be improved and achieve company goals. To determine the relationship of talent management programmes on employee performance is influenced by employee retention. Management talent is a system that must be considered by the company. With the management of the talent that applied to the company's employees feel the company can help them to develop their career through the talents that exist in the employees themselves. To develop his career, employees focuses not only on talent but employees should also pay attention to its performance to be able to improve his position within the company. Thus, the company can reduce employee retention moreover, the company can retain talented employees such as an asset in the future.

The results of the analysis of the descriptive statistics on the variables of management talent of respondents categorized very high. The results also showed that most of the employees working over 5 years, meaning that employees can improve their careers by following the process management talents so that the performance obtained from such employees will increase and will have an impact on retention of employees where the company retain employees who have the competence and talent to be able to advance the company.

This research is in line with research conducted by Rahmawati (2019) with the results of the research which states that management talents positive effect of employee performance through employee retention. It is also supported by Ramadhani (2020) the research results suggested that management talent has positive and significant effect on employee performance through employee retention.

\section{Knowledge Management Has Positive And Significant Effect On Employee Performance Through Employee Retention}

Based on the test Path Coefficient shows that knowledge management has positive and significant effect on employee performance through employee retention, then the hypothesis is accepted. The results of the research hypothesis suggest that knowledge management has positive and significant effect on employee performance at BGR Logistics through employee retention. Based on the results of the calculation of the influence directly or indirectly showed that the retention of the employees are able to provide mediation partially between knowledge management on the performance of employees. Influence in the form of indirect can be said as the influence of the variables of knowledge management on employee performance through employee retention.

The influence of the mediation is partial in the variable retention of employees at BGR Logistics, with the application of knowledge management given by the company to employees, employees will be more eager to do the job. Moreover, if the purpose of the employee hand in hand with the company's goals. It is certainly going to be very good for the performance of the employees and also the company. Knowledge that has set the company in a concept called knowledge management can help in the management of 
corporate knowledge to generate competitive advantage by optimizing the process of communicating and applying the knowledge needed in the process of achieving business objectives. So the performance of employees can be increased due to the existing knowledge in the company continue to exist and flow so that employees do not lack information that would help her in completing the work.

In this case the retention of employees as an intervening variable has an influence on knowledge management on the performance of the employee where the knowledge management performance of employees will increase. Employee performance increases will make the company retain employees what is more on the employees who have the competence to be able to advance the company both now and in the future.

This is supported by research conducted Harahap (2018), Hall (2019) and Ramadhani (2020) the research results suggested that knowledge management has positive and significant effect on employee performance through employee retention.

\section{CONCLUSIONS AND RECOMMENDATIONS CONCLUSIONS}

Based on the results of research and discussion that has been described in the previous chapter, it can be concluded as the following:

1. Partial management talents positive and significant effect on employee retention BGR Logistics.

2. Partial knowledge management have a positive and significant impact on employee retention BGR Logistics.

3. The partial retention of employees has positive and significant effect on employee performance BGR Logistics.

4. Partial management talent has positive and significant effect on employee performance BGR Logistics.

5. Partial knowledge management has positive and significant effect on employee performance BGR Logistics.
6. Partial management talent has positive and significant effect on employee performance through employee retention as an intervening variable on the BGR Logistics.

7. Partial knowledge management has positive and significant effect on employee performance through employee retention as an intervening variable on the BGR Logistics.

\section{RECOMMENDATIONS}

\section{For BGR Logistics}

To improve the system of management talents, BGR Logistics should give the opportunity to all employees to follow the system Management Development Program (MDP). These programs can help employees to be able to survive in the company so that the performance obtained will be increased, such a program can be done by the process of recruitment of talented employees in an open and healthy, provide adequate support such as motivating employees to continue to grow, give suggestions and feedback to employees, as well as provide training periodically in accordance with the description of his work both online and offline.

BGR Logistics should pay attention also to the management of knowledge by giving an opportunity to all employees to be able to access the data so that the company may obtain information that can help with the work. In addition to the superiors should be able to help his subordinates with work experience that has so employees gain new knowledge. So also with knowledge sharing, companies must foster a culture of knowledge sharing among employees either through group social media and openly as speech that can be performed each of the activities apples in the morning or monthly meeting.

So the preservation of employee retention to improve the performance of employees BGR Logistics suggested providing flexible work hours such as setting regulations should not enter the 
office each day so as to give good impact to the health of the employees. Companies also need to give the award competitive, meritbased performance, the recognition of employees as well as special bonuses. Thus employees are able to survive on the company with the maximum period of time or until the completion of the target company.

\section{For Further Research}

Preferably on the research can further develop this research that not only focuses on intervening variables but can also focus on the moderating variables so that this study can be used as a comparison.

\section{Acknowledgement: None}

\section{Conflict of Interest: None}

\section{Source of Funding: None}

\section{REFERENCES}

1. Arikunto Suharsimi. (2011). Prosedur Penelitian (Edisi Revisi). Jakarta: Rineka Cipta.

2. Cappelli, P., \& Keller, J. (2014).Talent Management: Conceptual Approaches and Practical Challenges. Annual Review of Organizational Psychology and Organizational Behavior,, 1(1), 305-331.

3. Cooke, F. L., Saini, D. S. \& Wang, J. (2014).Talent management in China and India: A comparison of management perceptions and human resource practices. Journal of World Business, 49, 225-235.

4. Davies, B., and Davies, B.J. (2010).Talent management in academics. International Journal of Educational Management, 24(5), 418-426.

5. Erlinda, N., Suryaningtyas, D., \& Suharso, A. A. P. (2020). Pengaruh Retensi dan Kompetensi Terhadap Kinerja Karyawan PT Taspen (Persero) Kantor Cabang Malang. Jurnal Riset Mahasiswa Manajemen, \%(2). https://doi.org/10.21067/jrmm.v5i2.4079.

6. Eka Ramadhani, Ferra., Harsono., Sunardi. (2020). Talent Management dan Knowledge Management Terhadap Kinerja Karyawan dengan Employee Retention Sebagai Variabel Moderator. Jurnal Bisnis dan Manajemen. Universitas Merdeka Malang.
7. Garvin, D.A. (2000). Learning in Action- A guide to Putting the Learning Organization to Work. Harvard.

8. Ghozali, Imam. (2011). Aplikasi Analisa Multivariate dengan program SPSS, Edisi Lima. Semarang: Badan Penerbit Universitas Diponegoro.

9. Harahap, Sonafa Mayrani Muchtar. (2018). "Pengaruh Talent Management Dan Knowledge Management Pada Employee Performance Dengan Employee Engagement Sebagai Variabel Intervening Di Bpjs Ketenagakerjaan Kantor Cabang Samarinda, Banjarmasin Dan Bontang". Tesis Magister Manajemen. Fakultas Ekonomi, Universitas Islam Indonesia.

10. Harmen, Hilman. (2018). "Pengaruh Talent Management dan Knowledge Management Terhadap Kinerja Karyawan PT Perkebunan Nusantara II (Survei Pada Kantor Direksi Tanjung Morawa)". Jurnal Konsep Bisnis dan Manajemen, p-ISSN: 24072648 eISSN: 2407-263X, Vol 4 (2). Jurusan Manajemen FE Unimed, Medan.

11. Izwar, H.\& Aerni, I. (2014).Talent management practices and employee engagement: A study in malaysian Glcs. Isa International Journal of Business, Economics and Law, Vol. 4, Issue 1 (June).

12. Jyoti, J. and Rani, R. (2014).Exploring talent management practices: Antecedents and consequences. International Journal of Management Concepts and Philosophy, 8(4)

13. Katili, Putri Buana, dkk. 2015. "Pengaruh Manajemen Talenta Dan Kompetensi Terhadap Kinerja Karyawan" Jurnal Seminar Nasional IENACO. ISSN 23374349, Hal. 618-625. Universitas Sultan Ageng Tirtayasa.

14. Kaur, A. (2013). Maslow's Need Hierarchy Theory: Applications and Criticisms. Global Journal of Management and Business Studies, 3(10), 1061-1064.

15. Kardo, K., Wilujeng, S., \& Suryaningtyas, D. (2020). Pengaruh Manajemen Talenta dan Manajemen Pengetahuan Terhadap Kinerja Karyawan Di Transformer Center Kabupaten Batu. Jurnal Riset Mahasiswa Manajemen, $\quad 6(1)$. https://doi.org/10.21067/jrmm.v6i1.4466

16. Kosasih, Natalia.,\& Budiani, Sri. (2007). Pengaruh Knowledge Management terhadap Kinerja Karyawan: Studi Kasus Departemen Front Office Surabaya Plaza Hotel. Jurnal 
Manajemen Perhotelan, Fakultas EkonomiUniversitas Kristen Petra.

17. Mangusho, Yona Sakaja, dkk. 2015. "Evaluation of Talent Management on Employees Performance in Beverage Industry: A Case of Delmonte Kenya Limited" International Journal of Humanities and Social Science. ISSN 22208488 (Print), 2221-0989 (Online).Vol. 5, No. 8, Hal.191-199. Kenya.

18. Mensah, James Kwame (2015). A "coalesced framework" of talent management and employee performance: For further research and practice. International Journal of Productivity and Performance Management, 64(4), 544-566, https://doi.org/10.1108/IJPPM-07-20140100.

19. Nidan, P.P. (2016). To Study The Impact of Employee Engagement on employee productivity and motivational level of employee in retail sector. IOSR Journal of Business and Management PP41-47.

20. Nisa,R.C., Astuti, E.S., \& Prasetya, Arik (2016). Pengaruh Manajemen Talenta dan Manajemen Pengetahuan terhadap Kinerja Karyawan (Studi Pada Karyawan PT.PLN (Persero) distribusi Jawa Timur, Surabaya). Jurnal Administrasi Bisnis (JAB), Vo.39, No.2.

21. Oladopo, Victor. 2014. The Impact of Talent Management on Retention.Journal of Business Studies Quarterly Vol 5(3).

22. Pella, Darmin A dan Inayati, Afifah. 2011. Talent Management (Mengembangkan SDM Untuk Mencapai Pertumbuhan dan Kinerja Prima). Jakarta: PT Gramedia Pustaka Utama.

23. Putri Dewi Ratnawati, D. \& Subudi, M. (2018). Pengaruh Talent Management Terhadap Employee Retention dengan Employee Engagement Sebagai Variabel Mediasi, 7(11). ISSN: 2302-8912.

24. Rahman, A \& Hasan, N. (2017).Modeling Effects of KM and HRM Processes to the Organizational Performance and Employee's Job Satisfaction.International Journal of Business and Management Vol. 12, No. 7: 35-45.

25. Aula Rahmawati, Hanum. (2019). Pengaruh Manajemen Talenta Terhadap Kinerja Karyawan Melalui Retensi Karyawan Pada PD BPR BANK Daerah Lamongan. Jurnal Ilmu Manajemen, 7(2). E-ISSN: 2549192X.
26. Ridwan dan Achmad.2012.Cara Menggunakan dan Memakai Path Analysis (Analisis Jalur). Bandung: Alfabeta.

27. Sari Puji Suryanti, W., Wilujeng, S., \& Suryaningtyas, D. (2021). Pengaruh Kompetensi, Komunikasi, dan Manajemen Pengetahuan (Knowledge Management) Terhadap Kinerja Pegawai Pada Dinas Pariwisata Kota Batu.Jurnal Riset Mahasiswa Manajemen, 7(1). https://doi.org/10.21067/jrmm.v7i1.5394

28. Schiemann, W.A. (2014). From talent management to talent optimization. Journal of World Business, 49, 281-288.

29. Sinulingga, S. 2014. Metode Penelitian, Edisi Ketiga. Medan: USU Press.

30. Situmorang, Syafrizal, $H$ dan Lutfi, M. 2014. Analisa Data : Untuk Riset Manajemen Bisnis. Edisi Ketiga. Medan: USU Press.

31. Sugiono. 2015. Metode Penelitian Kuantitatif Kualitatif dan R\&D. Bandung: Alfabeta.

32. Sulistiyana. 2021. Pengaruh Talent Management Terhadap Employee Retention dengan Employee Engagement Sebagai Variabel Mediasi. Universitas Teknologi Yogyakarta.

33. Sumarni, Murti. 2011. Pengaruh Employee Retention Terhadap Turnover Intention dan Kinerja Karyawan. Akmenika Vol. 8 bulan Oktober.

34. Sumarni, Murti. 2018. Dampak Talent Management Terhadap Employee Retention Pada Millenials Workforce.Jurnal Akuntansi \& Manajemen Akmenika Vol.15 No.1.Universitas PGRI Yogyakarta.

35. Syahputra, Bobby Wahyu dan Syarifuddin. 2016. "Analisis Faktor Talent Management Pada Kinerja Dosen Fakultas Komunikasi dan Bisnis Universitas Telkom". Jurnal eProceeding of Management.ISSN 23559357.Vol. 3, No. 2, Hal.1-9.Fakultas Komunikasi dan Bisnis, Universitas Telkom.

36. Tobing LL, Siahaan E, Silalahi AS, Role of leadership, workload, and compensation on temporary staffperformance within police unit in Tapanuli Tengah Regency. International Journal of Research and Review. 2021; 8(3): 467-476.

37. Tze San, Mei Theen \& Boon Heng (2012).The Reward Strategy and Performance Measurement (Evidence from Malaysian Insurance 
Nidya Banuari et.al. Analyze the influence of talent management and knowledge management on employee performance through employee retention as intervening variable at PT Bhanda Ghara Reksa Divre I Medan.

Companies).International Journal of How to cite this article: Banuari N, Absah Y, Business, Humanities and Technology, Vol. Siahaan E. Analyze the influence of talent 2 No. 1.

38. Valverde, M., Scullion, H. \& Ryan, G. (2013).Talent management in Spanish medium-sized organizations. The International Journal of Human Resource Management, 24(9), 1832-1852. management and knowledge management on employee performance through employee retention as intervening variable at PT Bhanda Ghara Reksa Divre I Medan. International Journal of Research and Review. 2021; 8(9): 189-204. DOI: https://doi.org/10.52403/ijrr. 20210926 